\title{
Statistic Model for the Estimation of the Resistance of Landing Craft Hulls
}

\author{
Modelo estadístico para la estimación de resistencia al avance de barcazas.
}

DOI: https://doi.org/10.25043/19098642.197

Cristian P. Vargas M. ${ }^{1}$
Gonzalo Tampier B. ${ }^{2}$
Marcos Salas I. ${ }^{3}$
Cristian Cifuentes S. ${ }^{4}$

\begin{abstract}
One of the most important challenges in the development of the preliminary project of a ship is the estimation of propulsive power. This calculation can become a challenge for landing craft projects, since no specific estimation method for these ships is available, considering their special form characteristics. Using a systematized test database carried out in the ship model ba-sin of Universidad Austral de Chile, a statistical model was generated through a multiple linear regression process to obtain an expression that serves to estimate the resistance for landing craft in preliminary stages of the project. Finally, the results of the regressions were compared with field measurements of 3 vessels in operation, showing a good agreement.
\end{abstract}

Key words: Landing craft, Ship resistance, Multiple linear regression.

\section{Resumen}

Siendo la resistencia al avance de una embarcación uno de los puntos principales a determinar en el proyecto, no se conoce una metodología específica para este especial tipo de buques. Utilizando una base de datos sistematizada de ensayos de barcazas efectuados en el Canal de Ensayos Hidrodinámicos de la Universidad Austral de Chile, los cuales fueron sometidos a una correlación modelo - buque siguiendo las recomendaciones de la ITTC-78, con algunos cambios; y mediante la utilización de modelos estadísticos basados en regresión lineal múltiple se obtuvieron 2 formulas, las que fueron comparadas con mediciones a bordo de 3 barcazas operativas.

Palabras claves: Barcazas, Resistencia al Avance, Regresión Lineal Múltiple.

Date Received: January 25 2019 - Fecha de recepción: Enero 25 de 2019

Date Accepted: February 28 2019 - Fecha de aceptación: Febrero 28 de 2019

\footnotetext{
${ }^{1}$ Astilleros ACN. Valdivia, Chile. Email: cristianpvargasm@gmail.com

${ }^{2}$ Universidad Austral de Chile. Valdivia, Chile. Email: gonzalo.tampier@uach.cl

${ }^{3}$ Universidad Austral de Chile. Valdivia, Chile. Email: msalas@uach.cl

${ }^{4}$ Universidad Austral de Chile. Valdivia, Chile. Email: cristiancifuentes@uach.cl
} 


\section{Introduction}

The estimation of ship resistance in early project stages is of great importance, allowing the designer to evaluate hull shape, and estimate the propulsive power required. In the case of landing craft and barge-shaped forms, this initial estimate is difficult, due to the limited information and methods available to be used.

The presentwork seeks to develop astatistical method to estimate the total resistance landing craft, using an estimation method prepared with information obtained from 520 model tests, which took place at the Hydrodynamic Test Facility (Canal de Ensayos Hidrodinámicos) of Universidad Austral de Chile (CEH-UACh). The proposed estimation method systematizes these data and processes them. Once the data is processed, multiple linear regressions were carried out, comparing these results with field measurements of barges in operation. These comparisons confirm the proposed formula for the estimation of ship resistance in calm waters for similarly shaped ships in preliminary design stages of vessels of this type.

\section{Landing Craft use for commercial applications}

Landing craft are usually small and medium vessels used for both military and civilian use.
Their main characteristic is their ability to land on beaches using a lowerable ramp in their bow. First accounts of landing craft in Chile were given during the landing in Pisagua (1879), where flatbottomed landing craft called "chalanas" were built to transport troops to the shore. During World War I, motorized landing craft with a ramp at the bow "X-lighters", were used for the mobilization of troops. Besides military use, landing craft have found different applications in regions with limited port infrastructure, limited water depth and/or the need of a large deck area. In Chile, landing craft vessels are widely used today for transportation of goods and support of aquaculture activities in the sheltered waters of the southern regions. These vessels provide large stability, large deck area, low draft and can land on beaches or ramps, providing ease of operation, despite their less optimal hydrodynamic performance. In Fig. 1, an example of a typical commercial landing craft is shown. As of today, around 300 landing craft vessels operate only for the aquaculture industry in Chile, being the most used vessel type in the aquaculture industry.

\section{Database consolidation and data processing}

The experimental data used for the preparation of the database came entirely from landing craft tank tests from the Hydrodynamic Test Tank

Fig. 1. Civilian landing craft for aquaculture support activities

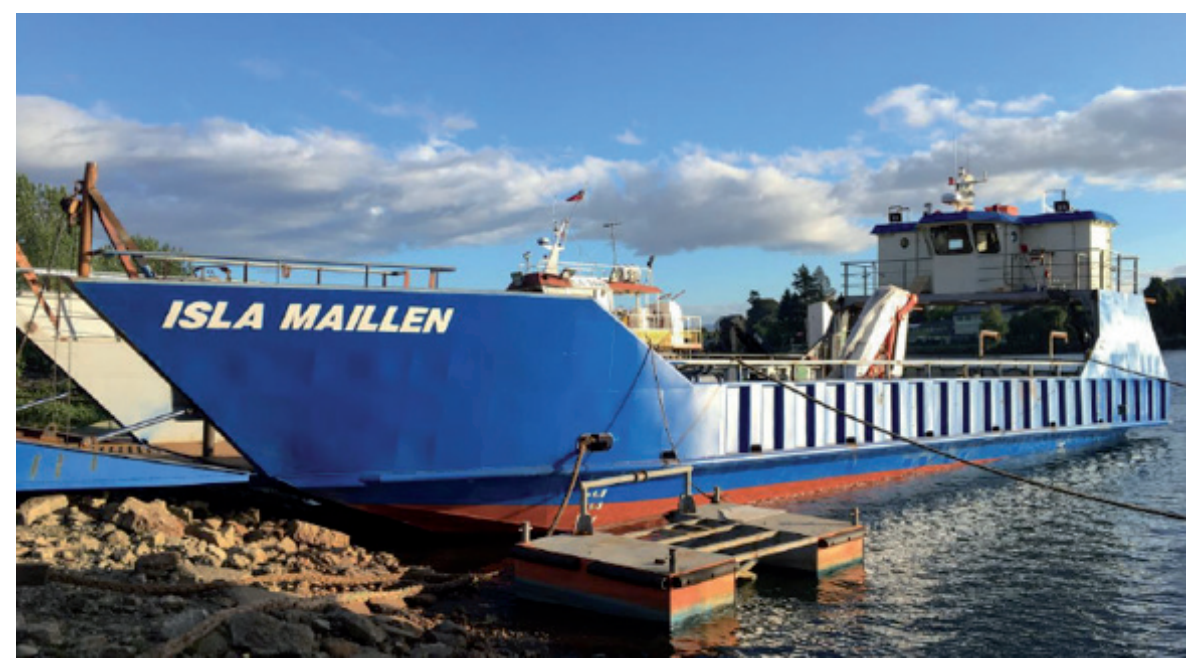


Table 1. Descriptive statistics of the landing craft database (dimensional data).

\begin{tabular}{|c|c|c|c|c|c|c|c|c|}
\hline Description & $L_{W L}(\mathbf{m})$ & $B_{W L}(\mathbf{m})$ & $T(\mathbf{m})$ & $C_{B}$ & $S\left(\mathbf{m}^{2}\right)$ & $\Delta(\mathbf{t})$ & $\nabla\left(\mathbf{m}^{3}\right)$ & $\begin{array}{c}V_{S} \\
(\mathrm{~m} / \mathrm{s})\end{array}$ \\
\hline Minimum & 14,080 & 2,400 & 0,260 & 0,472 & 46,000 & 15,990 & 15,600 & 0,000 \\
\hline Maximum & 20,000 & 12,000 & 1,900 & 0,840 & 322,400 & 322,834 & 314,960 & 7,155 \\
\hline 1st Quartile & 16,150 & 4,000 & 0,700 & 0,737 & 84,840 & 39,379 & 38,419 & 2,236 \\
\hline Median & 17,000 & 5,000 & 1,060 & 0,771 & 107,600 & 66,152 & 64,538 & 3,578 \\
\hline 3rd Quartile & 18,720 & 5,000 & 1,360 & 0,805 & 129,280 & 93,683 & 91,398 & 4,472 \\
\hline Mean & 17,302 & 5,603 & 1,055 & 0,748 & 128,117 & 79,053 & 77,125 & 3,304 \\
\hline Variance (n-1) & 3,081 & 10,032 & 0,162 & 0,008 & 4878,577 & 4170,302 & 3969,354 & 2,971 \\
\hline $\begin{array}{l}\text { Typical } \\
\text { deviation (n-1) }\end{array}$ & 1,755 & 3,167 & 0,403 & 0,087 & 69,847 & 64,578 & 63,003 & 1,724 \\
\hline
\end{tabular}

from Universidad Austral de Chile (CEH-UACh), carried out between 1990 and 2016. Part of these tests correspond to early systematic series [1] [2], [3]. Another part came from tests for landing craft projects built by Chilean shipyards. 520 tests were used, which were consolidated in a database. The descriptive statistics of the database are shown in Table 1 (full scale dimensions) and in Table 2 (nondimensional coefficients).

\section{Modeling and regression process}

A multiple linear regression model was used, due to the presence of more than one independent variable.
Since most parameters are linear within the scope of this work, a linear regression was considered adequate at this stage. To solve the regression model, the method of ordinary least squares or linear least squares was used. To work with this method, it must be verified that the database does not present multicollinearity or autocorrelation. Additionally, independent variables must be exogenous to the dependent variables [4].

A total of 8 regressions were performed. By changing independent variables and delimiting the database to different parameters, different expressions were obtained to compare and select. From an error analysis and considering the

Table 2. Descriptive statistics of the landing craft database (non-dimensional data).

\begin{tabular}{|c|c|c|c|c|c|}
\hline Description & $F_{N}$ & $\boldsymbol{R}_{N}$ & $C_{T M}$ & $\begin{array}{c}C_{F M}(I T T C- \\
57)\end{array}$ & $C R$ \\
\hline Minimum & 0,000 & 0,000 & 0,000 & 0,000 & 0,000 \\
\hline Maximum & 0,556 & 1,397E6 & 4,846E-02 & $7,504 \mathrm{E}-03$ & $4,278 \mathrm{E}-02$ \\
\hline 1st Quartile & 0,171 & 0,371E6 & 1,324E-02 & 4,751E-03 & 7,654E-03 \\
\hline Median & 0,260 & $0,571 \mathrm{E} 6$ & $1,607 \mathrm{E}-02$ & $5,154 \mathrm{E}-03$ & $1,070 \mathrm{E}-02$ \\
\hline 3rd Quartile & 0,351 & $0,780 \mathrm{E} 6$ & $2,061 \mathrm{E}-02$ & $5,648 \mathrm{E}-03$ & $1,556 \mathrm{E}-02$ \\
\hline Mean & 0,254 & $0,570 \mathrm{E} 6$ & 1,642E-02 & 4,790E-03 & $1,163 \mathrm{E}-02$ \\
\hline Variance (n-1) & 0,017 & $9,982 \mathrm{E} 10$ & $6,39 \mathrm{E}-05$ & $2,988 \mathrm{E}-06$ & $5,03 \mathrm{E}-05$ \\
\hline $\begin{array}{l}\text { Typical } \\
\text { deviation (n-1) }\end{array}$ & 0,131 & $0,316 \mathrm{E} 6$ & 7,994E-03 & $1,729 \mathrm{E}-03$ & 7,097E-03 \\
\hline
\end{tabular}


Table 3. Multiple linear regressions for CR estimation.

\begin{tabular}{|c|c|c|c|}
\hline & DATASET & $\mathbf{N}^{\circ}$ OBS. & INDEPENDENT VARIABLES \\
\hline 1 & Full database & 520 & $F_{N}, L / \nabla^{1 / 3}, C_{B}, L_{W L} / \mathrm{B}, L_{W L} / T, B / T$ \\
\hline 2 & Full database & 520 & $F_{N}, C_{B}, L_{W L} / \mathrm{B}, L_{W L} / T, B / T$ \\
\hline 3 & $0.22 \leq F_{N} \leq 0.4$ & 247 & $F_{N}, L / \nabla^{1 / 3}, C_{B}, L_{W L} / \mathrm{B}, L_{W L} / T, B / T$ \\
\hline 4 & $0.22 \leq F_{N} \leq 0.4$ & 247 & $F_{N}, C_{B}, L_{W L} / \mathrm{B}, L_{W L} / T, B / T$ \\
\hline 5 & $0.22 \leq F_{N} \leq 0.4$ and $L / \nabla^{1 / 3}<6$ & 226 & $F_{N}, C_{B}, L_{W L} / \mathrm{B}, L_{W L} / T, B / T$ \\
\hline 6 & $0.22 \leq F_{N} \leq 0.4$ and $L / \nabla^{1 / 3}<6$ & 226 & $F_{N}, L / \nabla^{1 / 3}, C_{B}, L_{W L} / \mathrm{B}, L_{W L} / T, B / T$ \\
\hline 7 & $0.22 \leq F_{N} \leq 0.4$ and $L / \nabla^{1 / 3}<6$ & 226 & $F_{N}^{2}, L / \nabla^{1 / 3}, C_{B}, L_{W L} / \mathrm{B}, L_{W L} / T, B / T$ \\
\hline 8 & $0.22 \leq F_{N} \leq 0.4$ and $L / \nabla^{1 / 3}<6$ & 226 & $F_{N}{ }^{2}, L / \nabla^{1 / 3}, C_{B}, C_{M}, L_{W L} / \mathrm{B}, L_{W L} / T, B / T$ \\
\hline
\end{tabular}

limitations of certain data, a subset limiting the Froude number $0.22 \leq F_{N} \leq 0.4$ and the slenderness coefficient $L / \nabla^{\wedge}(1 / 3)<6$ was preferred, considering 7 independent variables, as shown in dataset 8 (last row) of Table 3.

The recommended minimum and maximum values of the independent variables for the selected dataset are given in Table 4. The obtained formula for the estimation of the residual resistance coefficient is given in section 5 .

\section{Resistance prediction}

For the present investigation, Froude's method is used for the total resistance coefficient estimation using the following workflow.

Table 4. Recommended limits for the independent variables.

\begin{tabular}{|c|c|c|c|}
\hline & Variable & Min. & Max \\
\hline 1 & $F_{N}$ & 0,22 & 0,40 \\
\hline 2 & $L / \nabla^{1 / 3}$ & 3 & 6 \\
\hline 3 & $C_{B}$ & 0,5 & 0,8 \\
\hline 4 & $C_{M}$ & 0,6 & 1 \\
\hline 5 & $L_{W L} / B$ & 3 & 7 \\
\hline 6 & $L_{w L} / T$ & 12 & 30 \\
\hline 8 & $B / T$ & 1,5 & 10 \\
\hline
\end{tabular}

a) Residual resistance coefficient estimated according to the expression:

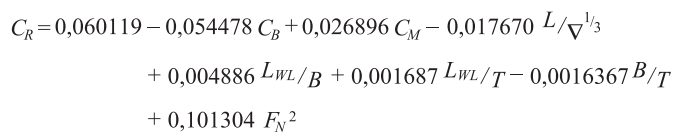

b) Friction correlation line according to ITTC-57:

$$
C_{F}=\frac{0,075}{\left(\log \left(R_{N}\right)-2\right)^{2}}
$$

c) Wind resistance according to the expression:

$$
C_{A A}=0,001^{A}{ }^{T} / S
$$

d) Correlation allowance [5]

$$
C_{A}=0,105\left({ }^{k_{s} / L}\right)^{1 / 3}-0,00064
$$

e) Total resistance coefficient is then defined:

$$
C_{T}=C_{R}+C_{F}+C_{A A}+C_{A}
$$

Appendages, added resistance in waves, and other effects can be added if required.

\section{Determination of model effectiveness}

To verify the effectiveness of the obtained model, results were compared with data from real vessels in which power versus speed measurements were 
available. Additionally, results were compared with results from an estimation for barges proposed by KR [6]. Although the KR method is proposed as an estimation for the towing force needed for unpropelled barges, it is widely used today by naval architects in early design stages for landing craft, mainly due to the lack of more adequate methods. Data from 3 vessels of similar characteristics as those contained in the database were used (see Table 5).
In Fig. 2, results for the selected model are compared with data from sea trials for one of the analyzed vessels (Isla Picton). Additionally, resistance results from the KR method are shown using two bow shape factors (F2 $=0,3$ and 0,5$)$. These shape factors represent the limits for landing craft shaped bows according to the KR method. From results, a good agreement can be seen for the presented method, although more validation is necessary.

Table 5. Characteristics of landing craft used for model verification.

\begin{tabular}{|c|c|c|c|}
\hline & ISLA LENNOX & ISLA PICTON & ISLA MAILLEN \\
\hline$L_{W L}$ & $18,172 \mathrm{~m}$ & $20,586 \mathrm{~m}$ & $21,010 \mathrm{~m}$ \\
\hline$B_{W L}$ & $6,47 \mathrm{~m}$ & $6,22 \mathrm{~m}$ & $6,652 \mathrm{~m}$ \\
\hline$T$ & $1,05 \mathrm{~m}$ & $1,03 \mathrm{~m}$ & $1,01 \mathrm{~m}$ \\
\hline$\nabla$ & $105,4 \mathrm{~m}^{3}$ & $109,7 \mathrm{~m}^{3}$ & $123,55 \mathrm{~m}^{3}$ \\
\hline$C_{B}$ & 0,689 & 0,659 & 0,68 \\
\hline$L_{w l} / B_{w l}$ & 2,808 & 3,3 & 3,16 \\
\hline$L_{w l} / T$ & 17,3 & 19,98 & 20,8 \\
\hline$B_{W l} / T$ & 6,1619 & 6,039 & 6,58 \\
\hline$L_{w L} / \nabla^{1 / 3}$ & 3,85 & 4,3 & 4,22 \\
\hline$P_{B}$ & $240 \mathrm{HP} \times 2$ & $240 \mathrm{HP} \times 2$ & $360 \mathrm{HP}$ x 2 \\
\hline
\end{tabular}

Fig. 2. PE v/s VS, from sea trials and proposed method for "Isla Picton" landing craft. Simi-lar results were obtained for the remaining ships.

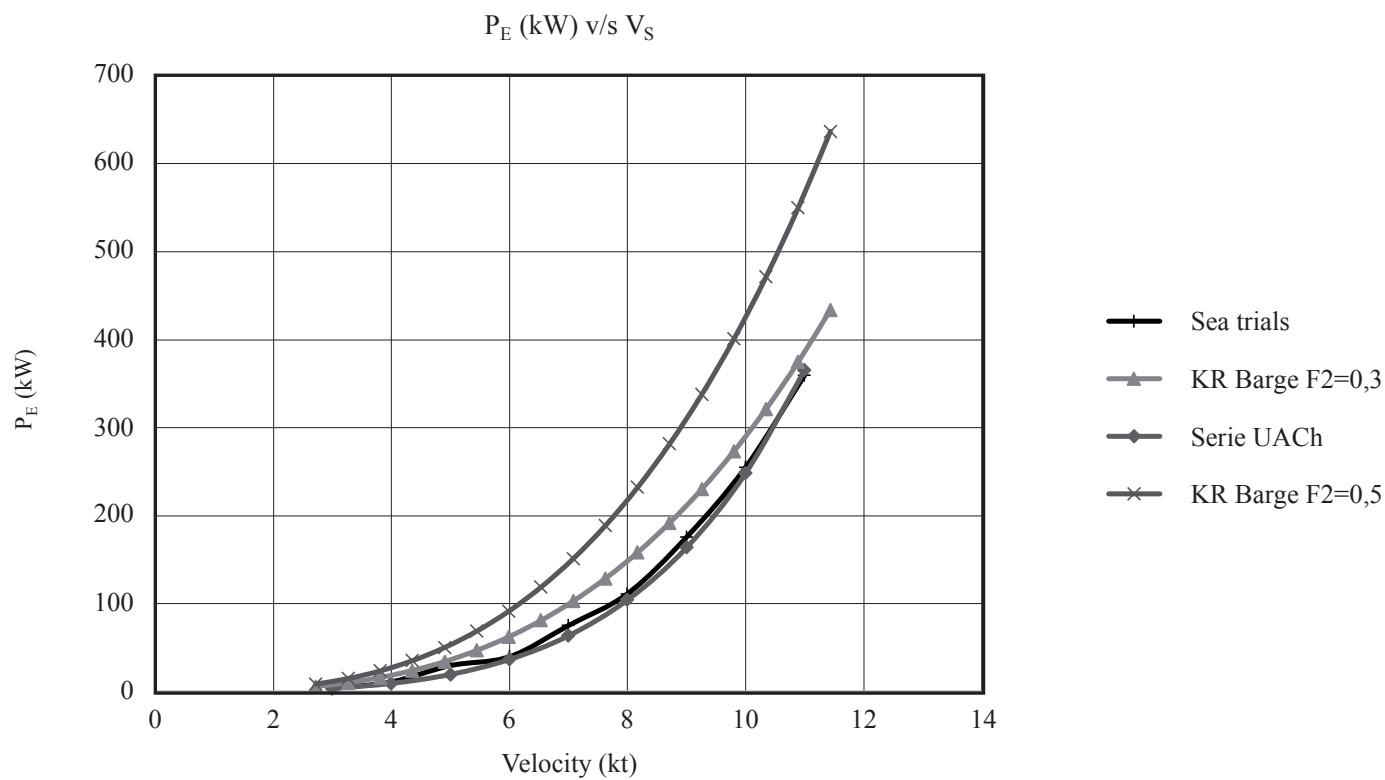




\section{Conclusions}

Although there are numerous methods to empirically obtain the total resistance of a ship, none of them incorporates landing craft vessels. The presented methodology can still be improved by considering more form parameters (e.g. bow and stern shape), data reanalysis, and a deeper validation process. Nevertheless, results can be considered as encouraging and, within the limitations of the considered form parameters, useful in early stages of design. It is important to emphasize that results should be interpreted with care and should not replace experiments or numerical simulations at later stages of design.

\section{References}

[1] C. FONFACH, "Resistencia al avance en barcazas con diferentes secciones transversales", Universidad Austral de Chile, 1991.
[2] J. GONZÁLEZ, "Influencia en la Resistencia al avance de algunas formas de proa en una barcaza", Universidad Austral de Chile, 1990.

[3] J. MIÑO, "Serie sistemática de gabarras I.," Universidad Austral de Chile, 1993.

[4] C. P. VARGAS MUÑOZ, "Estimación de Resistencia al Avance de Barcazas en las Etapas preliminares del Diseño utilizando un Modelo Estadistico Basado en Series Sistemáticas", Universidad Austral de Chile, 2018.

[5] B. S. BOWDEN AND DAVISON N.J., "Resistance Increments Due to Hull Roughness Associated with Form Factor Extrapolation Methods", 1974.

[6] K. KOREAN REGISTER, "Rules for the Towing Survey of Barges and Tugboats”, 2014. 